Volume 3 Nomor 1, Februari 2018, halaman 1-10

\title{
PENDEKATAN KETERAMPILAN METAKOGNITIF DALAM PEMBELAJARAN MATEMATIKA
}

\section{METACOGNITIVE SKILL APPROACH IN LEARNING MATHEMATICS}

\author{
Kurnia Putri Sepdikasari Dirgantoro \\ Universitas Pelita Harapan, Jln. M. H. Thamrin Boulevard 1100 Lippo Village Tangerang \\ Banten 15811, kurnia.dirgantoro@uph.edu
}

\begin{abstract}
ABSTRAK
Pola pikir zaman sekarang yang menuntut segala sesuatu menjadi serba cepat dan instan sering kali terbawa oleh siswa di sekolah. Ketika mengerjakan soal, siswa akan merasa puas ketika mereka sudah menemukan jawabannya. Entah jawabannya benar atau tidak, sangat jarang ditemui siswa yang kembali mengecek pekerjaan mereka. Di dalam proses pembelajaran pun, siswa dinilai kurang mampu dalam menganalisa kelemahan dan kelebihan yang dimilikinya untuk dapat memaksimalkan proses belajar. Mengerjakan seadanya yang penting selesai seringkali menjadi slogan para siswa saat ini. Padahal kemampuan menganalisa kelemahan maupun kelebihan yang dimiliki adalah kemampuan yang penting, khususnya dalam belajar matematika. Kesadaran akan kelebihan dan kekurangan ini dinamakan kesadaran metakognisi. Dalam belajar matematika keterampilan ini perlu dikembangkan. Untuk itu artikel ini akan membahas mengenai pembelajaran matematika dengan menggunakan pendekatan keterampilan metakognitif.
\end{abstract}

Kata kunci: Keterampilan Metakognitif, Pembelajaran Matematika

\begin{abstract}
Today's mindset that demands everything to be fast-paced and instant is often carried away by students at school. When working on a problem, students will feel satisfied when they have found the answer. Whether the answer is true or not, very rarely encountered students who re-check their work. In the learning process, students are considered less able in analyzing the weaknesses and advantages they have to be able to maximize the learning process. The crucial work done is often the slogan of today's students. Though the ability to analyze the weaknesses and advantages possessed is an important ability, especially in learning mathematics. This awareness of the advantages and disadvantages is called metacognition awareness. In learning mathematics this skill needs to be developed. For this article will discuss about mathematics learning using metacognitive skills approach.
\end{abstract}

Keywords: Metacognitive Skills, Mathematics Learning

How to Cite: Dirgantoro, K. P. S. (2018). Pendekatan Keterampilan Metakognitif dalam Pembelajaran Matematika. Mathline: Jurnal Matematika dan Pendidikan Matematika, Vol.3, No.1, 1-10. 


\section{PENDAHULUAN}

Belajar merupakan suatu proses yang berkesinambungan dan terjadi terus menerus sepanjang hayat. Oleh karena itu hal terpenting di dalam belajar bukanlah hasil, melainkan proses mendapatkan hasil tersebut. Di dalam proses belajar, seseorang memperoleh pengalaman dari yang tidak bisa menjadi bisa, dari yang tidak biasa menjadi terbiasa. Dan ketika mengalami suatu kegagalan dalam belajar, hal tersebut menjadi pengalaman dan pembelajaran berharga yang membuatnya terus bertumbuh.

Ketika mengalami kegagalan, siswa belajar untuk lebih mengenal dirinya, mengenal kelemahan maupun kekuatan yang dimiliknya. Kemampuan mengenal setiap kekuatan dan kelemahan yang dimiliki merupakan kemampuan yang perlu dimiliki oleh seseorang sehingga ia pada akhirnya dapat memiliki keyakinan bahwa ia dapat menyelesaikan permasalahan yang muncul. Kemampuan ini juga sangat diperlukan dalam belajar, termasuk dalam belajar matematika. Kemampuan dalam menyadari kelebihan dan kekurangan yang dimiliki dinamakan kesadaran metakognisi.

Metakognisi berasal dari kata metacognition yang mengandung prefiks meta dan kata cognition. Meta berasal dari bahasa Yunani yang berarti "setelah, melebihi, di atas", sedangkan cognition diartikan sebagai apa yang diketahui serta dipikirkan seseorang.

Istilah metakognisi diperkenalkan oleh John Flavell pada tahun 1970an (Livingston, 2003). Pendefinisian istilah ini menimbulkan banyak perdebatan. Menurut Flavell sendiri, metakognisi terdiri dari pengetahuan metakognitif (metacognitive knowledge) dan pengalaman atau regulasi metakognitif (metacognitive experiences or regulation). Pengetahuan metakognitif menunjuk pada diperolehnya pengetahuan tentang proses-proses kognitif, pengetahuan yang dapat dipakai untuk mengontrol proses kognitif. Sedangkan pengalaman metakognitif adalah proses-proses yang dapat diterapkan untuk mengontrol aktivitas-aktivitas kognitif dan mencapai tujuan-tujuan kognitif.

Metakognisi menekankan kesadaran individu terhadap proses berpikirnya sendiri atau tentang proses dan prosedur berpikir individu sebagai pemikir dan pelaku sehingga individu sadar dalam memonitor dan mengontrol aktivitas mental atau proses mental. Dengan kata lain, metakognisi adalah “thinking about thiking” (Livingston, 2003; Mahdavi, 2014; Sengul \& Katranci, 2012). Sehingga dapat disimpulkan bahwa metakognisi adalah kesadaran siswa terhadap kemampuan yang dimilikinya serta kemampuan untuk memahami, mengontrol dan memanipulasi proses-proses kognitif yang mereka miliki. 


\section{PENDEKATAN PEMBAHASAN}

Tulisan ini menggunakan pendekatan studi kepustakaan untuk memperoleh gambaran yang lebih jelas mengenai pendekatan metakognitif dalam pembelajaran matematika. Studi kepustakaan berkaitan dengan kajian teoritis dan referensi lain yang berkaitan dengan nilai, budaya dan norma yang berkembang pada situasi sosial yang diteliti (Sugiyono, 2013).

\section{HASIL DAN PEMBAHASAN}

\section{Metakognisi}

Metakognisi siswa perlu dikembangkan untuk dapat meningkatkan kualitas belajar. Flavell (Mahdavi, 2014) berpendapat meskipun dengan sedikit bukti empiris, metakognisi memainkan peran penting dalam berbagai area pembelajaran seperti komunikasi lisan dalam informasi, persuasi lisan, pemahaman lisan, pemahaman bacaan, penulisan, perolehan bahasa, perhatian, memori, pemecahan masalah, kognisi sosial, dan berbagai jenis pengendalian diri dan self-instruction. Mendukung hal tersebut, Chamot, et al. (Mahdavi, 2014) menyatakan bahwa metakognisi merupakan ciri khas pembelajar yang sukses.

Metakognisi dapat ditingkatkan melalui aktivitas latihan. Flavell (1976) mengemukakan bahwa aktivitas latihan dapat diberikan oleh: (1) orang tua; yang secara langsung mengajarkan keterampilan metakognitif untuk membantu anaknya mengatur dan memonitor tindakannya, (2) guru di sekolah yang memodelkan (Wall \& Hall, 2016), mengajarkan dan mendorong aktivitas metakognitif; guru dapat membantu siswa mengatur dan memantau kognisi diri sendiri, (3) membaca, (4) menulis, dan (5) mendengar secara kritis dan menyampaikan gagasan (berbicara) secara terampil (skilfull).

Salah satu upaya yang dapat membantu siswa menumbuhkan kesadaran kognisinya adalah dengan memberikan arahan agar siswa bertanya kepada dirinya sendiri. Upaya ini dilakukan agar siswa dapat mengontrol dan memonitor pemahaman mereka mengenai apa yang sedang dipelajarinya. Siswa diajak bertanya pada diri sendiri apakah mereka mengetahui apa yang sebenarnya sedang mereka pikirkan.

Schoenfeld (1992) menandai tiga kategori metakognisi dalam pembelajaran matematika, yaitu:

1. Keyakinan dan intuisi, yang merupakan proses metakognisi di mana sebelum seorang siswa mengerjakan suatu masalah, ia memiliki keyakinan bahwa masalah tersebut dapat diselesaikan dan memiliki intuisi bahwa masalah yang timbul dapat diselesaikan dengan 
ide-ide dan proses tertentu. Ini berarti siswa memiliki keyakinan diri bahwa ia dapat menyelesaikan masalah tersebut.

2. Pengetahuan mengenal proses berpikir seseorang, yang berkaitan dengan seberapa akurat seseorang dalam menyatakan proses berpikirnya. Seorang pemecah masalah yang baik menggunakan apa yang diketahuinya secara efisien. Pada bagian ini, Schoenfeld lebih menekankan pada proses pengorganisasian atau pengeloalaan pengetahuan yang berhubungan dengan proses berpikir dalam memecahkan masalah.

3. Kesadaran diri atau pengaturan diri, yang menggunakan pendekatan pengelolaan di dalam aspek-aspek: (a) mengases pemahaman terhadap masalah secara keseluruhan, (b) merencanakan strategi penyelesaian, (c) memonitor dan mengontrol cara-cara penyelesaian, (d) mengalokasikan hasil, memutuskan apa yang harus dilakukan dan berapa lama masalah tersebut diselesaikan.

\section{Pendekatan Keterampilan Metakognitif}

Metakognitif merupakan kata sifat metakognisi. Peningkatan keterampilan metakognitif, yang merupakan faktor kunci dalam menciptakan dan mempertahankan pembelajaran yang sukses, juga meningkatkan kualitas pembelajaran (Sengul \& Katranci, 2012). Suzana (2004) mendefinisikan pembelajaran dengan pendekatan keterampilan metakognitif sebagai pembelajaran yang menanamkan kesadaran bagaimana merancang, memonitor serta mengontrol apa yang diketahui, apa yang diperlukan untuk mengerjakan dan bagaimana melakukannya.

Blakey \& Spence (1990) mengemukakan enam strategi untuk mengembangkan perilaku metakognitif, yaitu: (1) identifying “what you know" and "what you don't know”, (2) talking about thinking, (3) keeping a thinking journal, (4) planning and self-regulation, (5) debriefing the thingking process, dan (6) self-evaluation. Ini berarti, pembelajaran dengan pendekatan keterampilan metakognitif membantu siswa untuk mengarahkan perhatiannya pada apa yang relevan dengan masalah dan membimbing mereka untuk memilih strategi yang cocok dalam menyelesaikan masalah tersebut melalui pertanyaanpertanyaan yang sesuai. Selanjutnya, Kramarski \& Mevarech (2003) mengelompokkan pertanyaan-pertanyaan tersebut ke dalam tiga set pertanyaan metakognitif yang ditujukan untuk diri siswa sendiri, yaitu strategic questions, connection questions, dan reflection questions. Strategic questions merupakan pertanyaan yang dapat membantu siswa mempertimbangkan strategi mana yang sesuai untuk menyelesaikan masalah yang sedang dihadapinya. Connection questions merupakan pertanyaan yang dapat membantu siswa memusatkan perhatian pada persamaan dan perbedaan antara yang masalah yang akan 
diselesaikan dengan masalah yang pernah berhasil diselesaiakan. Reflection questions merupakan pertanyaan yang dirancang agar siswa dapat merefleksikan pemahamannya selama proses pemecahan masalah tersebut.

Strategi pembelajaran metakognitif menurut Beyer memiliki tiga komponen utama, yaitu perencanaan, pemantauan dan penilaian (Tomo, 2003). Perencanaan meliputi: menyatakan tujuan, memilih operasi yang dipakai, mengurutkan operasi-operasi, mengidentifikasi cara-cara untuk mengatasi kesalahan dan hambatan, serta memprediksikan hasil yang diinginkan. Pemantauan meliputi: menjaga tujuan yang telah ditetapkan, menjaga urutan operasi yang sesuai dengan masalah yang dihadapi, memutuskan kapan menggunakan operasi berikutnya yang lain, mengetahui tujuan yang telah dicapai, memilih operasi yang paling sesuai, mengetahui hambatan dan masalah, serta mengetahui kapan kesulitan dan hambatan itu teratasi. Penilaian meliputi: menilai pencapaian tujuan, menimbang keakuratan dan ketepatan hasil-hasil, mengevaluasi kesesuaian prosedur yang digunakan, menilai penanganan kesulitan dan hambatan, serta menimbang efisiensi rencana dan pelaksanaannya.

\section{Tahap-Tahap Pengimplementasian Pendekatan Keterampilan Metakognitif dalam Pembelajaran}

Wilen \& Philips (1995) menyatakan bahwa pendekatan metakognitif dalam pembelajaran memiliki 3 tahap, yaitu:

1. Penjelasan oleh guru.

Pada tahap ini, guru menentukan keterampilan mana yang harus diajarkan pada siswa, mencantumkan langkah-langkah yang harus diikuti saat menjalankan keterampilan, dan menjelaskan mengapa hal tersebut penting dan kapan siswa perlu menggunakannya. Guru pun perlu menjelaskan proses penalaran dan menyajikan beberapa contoh dan non-contoh. Bersamaan dengan itu, guru mengantisipasi jenis masalah yang mungkin muncul dari siswa seperti mengenai kapan dan bagaimana menggunakan proses penalaran.

2. Pemodelan oleh Guru

Selain menjelaskan kemampuan berpikir kritis, guru pun perlu memodelkan proses kognitif yang terlibat dalam suatu pembelajaran. Guru menyatakan kapan dan bagaimana keterampilan berpikir harus digunakan. Guru menyediakan model proses berpikir dengan menyatakan apa yang sedang terjadi di dalam kepalanya. Di sini guru diasumsikan sebagai pemikir ahli sementara siswa dipandang sebagai pemula.

3. Pemodelan oleh Siswa 
Setelah siswa menyimak pemodelan oleh guru, selanjutnya siswa melakukan tugas yang sama di bawah bimbingan guru. Ketika siswa mulai menggambarkan apa yang sedang terjadi "di dalam kepala mereka," mereka menjadi sadar akan proses berpikir mereka. Guru membentuk pemahaman siswa tentang proses penalaran dengan meminta mereka untuk menjelaskan bagaimana mereka berpikir. Atas dasar apa yang siswa katakan, guru memberikan penjelasan tambahan untuk membantu mereka mengemukakan alasan dan menyampaikan argumen. Demikian pula, saat siswa mendengarkan teman sekelas mereka yang menggambarkan proses mentalnya, siswa mengembangkan fleksibilitas pemikiran dan penghargaan atas berbagai cara untuk memecahkan masalah yang sama. Siswa diminta untuk mengajukan pertanyaan, menemukan kebingungan, membentuk hipotesis, dan memberikan saran yang membangun terhadap kegagalan.

\section{Peran Guru dalam Membantu Siswa Meningkatkan Kemampuan Metakognisinya}

Mengingat pentingnya peranan metakognisi dalam kegiatan belajar maka upaya untuk mengingkatkan hasil belajar siswa dapat dilakukan dengan meningkatkan keterampilan metakognisi siswa (Kramarski \& Mevarech, 2003). Mengembangkan metakognisi siswa berarti membangun fondasi untuk belajar secara aktif. Guru sebagai perancang kegiatan belajar dan pembelajaran mempunyai tanggung jawab dan kesempatan untuk dapat mengembangkan metakognisi siswa.

Strategi yang dapat dilakukan guru dalam mengembangkan metakognisi siswa (Taccasu Project, 2008) adalah dengan (1) membantu siswa mengembangkan strategi belajarnya, dan (2) membimbing siswa dalam mengembangkan kebiasaan baik yang meliputi kebiasaan mengelola diri sendiri, kebiasaan berpikir positif, kebiasaan berpikir secara hierarkis dan kebiasaan bertanya.

Lovett (2008) menyatakan terdapat tiga tahap yang dapat dilakukan guru untuk dapat mengajarkan siswa mengembangkan kemampuan metakognisinya, yaitu: (1) mengajarkan siswa bahwa kemampuan belajar bukanlah kuantitas yang tetap namun dapat meningkat seiring berjalannya waktu sehingga keyakinan diri siswa pun terus terbentuk; (2) mengajarkan siswa bagaimana menetapkan tujuan dan membuat rencana untuk mencapainya; dan (3) memberikan kesempatan kepada siswa untuk dapat mempraktikkan pemantauan dan penyesuaian diri.

Sebelum proses tersebut, guru perlu terlebih dahulu mengetahui sejauh mana tingkat kemampuan metakognisi siswanya. Huitt (1997) memberikan contoh pertanyaan yang dapat diajukan guru untuk dapat mengungkapkan kemampuan metakognisi siswa, yaitu: (1) sudahkah para siswa memonitor belajar dan cara berpikir mereka, (2) sudahkah 
para siswa mempelajari strategi belajar, (3) sudahkah para siswa membuat prediksi tentang informasi yang akan dipresentasikan berdasarkan apa yang telah mereka baca, (4) sudahkah para siswa merelasikan ide-ide pada struktur pengetahuan, (5) sudahkah para siswa mengembangkan pertanyaan, bertanya pada diri sendiri tentang apa yang terjadi di sekeliling mereka, (6) sudahkah para siswa tahu kapan mereka harus meminta bantuan, dan (7) tunjukkan pada siswa bagaimana mentransfer pengetahuan, perilaku nilai, keterampilan pada situasi lain.

\section{Pendekatan Keterampilan Metakognitif dalam Kurikulum 2013}

Tujuan nasional pendidikan Indonesia telah tertuang sejak dahulu dalam UUD 1945. Pendidikan adalah alat yang digunakan untuk dapat mencerdaskan kehidupan bangsa, instrumen nasional dalam mengembangkan sumber daya manusia Indonesia (Tim Dosen, 2005).

Kurikulum merupakan salah satu faktor yang memegang peranan penting dalam pendidikan. Pengertian kurikulum terus berkembang seiring dengan perkembangan teori dan praktek pendidikan. BNSP (Badan Standar Nasional Pendidikan) menyatakan bahwa kurikulum adalah seperangkat rencana dan pengaturan mengenai isi, dan bahan pelajaran serta cara yang digunakan sebagai pedoman penyelenggaraan kegiatan pembelajaran untuk mencapai tujuan pendidikan tertentu (Ristekdikti, 2013).

Kurikulum yang saat ini berlaku di Indonesia adalah Kurikulum 2013. Prinsip pembelajaran yang digunakan dalam kurikulum ini adalah: (1) berpusat pada peserta didik, (2) mengembangkan kreativitas peserta didik, (3) menciptakan kondisi menyenangkan dan menantang, (4) bermuatan nilai, etika, estetika, logika, dan kinestetika, dan (5) menyediakan pengalaman belajar yang beragam (Kemendikbud, 2014). Sedangkan dalam pelaksanaan kegiatan pembelajaran, kurikulum 2013 menekankan pada pemilihan berbagai strategi dan metode pembelajaran yang menyenangkan, kontekstual, efektif, efisien, dan bermakna. Dalam hal ini kegiatan pembelajaran mampu mengembangkan dan meningkatkan kompetensi, kreativitas, kemandirian, kerjasama, solidaritas, kepemimpinan, empati, toleransi dan kecakapan hidup peserta didik guna membentuk watak serta meningkatkan peradaban dan martabat bangsa.

Dalam pelaksanaannya, pembelajaran dengan pendekatan keterampilan metakognitif memberikan kesempatan kepada siswa untuk dapat lebih aktif dalam mengonstruksi pemahamannya. Siswa dibimbing untuk dapat mengetahui seberapa besar kemampuan matematis yang dimilikinya sehingga ia dapat memonitor proses berpikirnya (Wilen \& Philips, 1995). Selain itu, dengan bimbingan guru, siswa dilatih untuk dapat 
melihat di mana letak kesalahannya dan dapat mengoreksi sendiri kesalahan yang dibuatnya sehingga mereka dapat menjadi lebih reflektif (Wilen \& Philips, 1995). Proses ini secara tidak langsung dapat memupuk kemandirian siswa dalam belajar (Du Toit \& Kotze, 2009). Guru tidak hanya membimbing siswa untuk dapat menyelesaikan permasalahan melainkan turut menanamkan keyakinan dalam diri siswa bahwa setiap permasalahan pasti dapat diselesaikan dengan cara-cara dan strategi tertentu. Hal ini sesuai dengan prinsip pembelajaran Kurikulum 2013 poin ke-2 dan ke-3. Sehingga dapat dilihat bahwa pendekatan keterampilan metakognitif merupakan inovasi pembelajaran yang sesuai dengan Kurikulum 2013.

\section{Keunggulan dan Kelemahan Pendekatan Keterampilan Metakognitif}

Pendekatan keterampilan metakognitif memiliki beberapa keunggulan, di antaranya adalah:

1. Mendorong siswa untuk belajar secara aktif. Pembelajaran matematika dengan pendekatan melatih siswa untuk dapat mengonstruksi sendiri konsep yang dipelajarinya melalui proses pemecahan masalah (Suzana, 2003). Siswa diberi keleluasaan untuk dapat mengembangkan proses berpikir dan bertanggung jawab atas pemikirannya sendiri.

2. Memberi kesempatan kepada siswa untuk mencapai pemahaman konsep dan proses (Wilen \& Philips, 1995).

3. Meningkatkan kemampuan pemecahan masalah dan kemampuan berpikir tingkat tinggi (Alshammari, 2015).

4. Memberi kesempatan siswa untuk belajar mandiri melalui pengerjaan soal-soal latihan yang diberikan guru (Suzana, 2003). Aktivitas ini dapat membantu mengurangi lupa dan meningkatkan ingatan serta pemahaman setelah pembelajaran, sadar apa yang dilakukan, bagaimana melakukan, bagaimana mencari penyelesaiannya.

5. Membantu siswa memahami teks soal secara lebih efektif (Bruce \& Robinson, 2002).

6. Suasana belajar lebih hidup, komunikasi terjadi multi arah, terjadi interaksi antara siswa (Wilen \& Philips, 1995).

Selain kelebihan, pendekatan keterampilan metakognitif pun memiliki kelemahan yang dapat terjadi dalam prakteknya. Adapun dengan dipaparkannya kelemahan ini diharapkan dapat diminimalisir.

1) Pada tahap awal pengimplementasian, beberapa siswa mungkin mengalami kesulitan dalam mengatur dan memantau diri sendiri dalam proses pembelajaran (Suzana, 2003). 
2) Pentingnya ketersediaan sumber belajar sebab siswa dituntut agar dapat belajar mandiri untuk mencapai pemahaman konsep (Suzana, 2003). Siswa diharapkan telah mempersiapkan diri dengan membaca materi yang akan dipelajari.

3) Cullen (Alshammari, 2015) mencatat bahwa metakognisi dapat mempengaruhi selfesteem siswa. Siswa yang lemah dalam metakognisi tidak dapat mengembangkan selfesteem dengan maksimal. Siswa dengan self-esteem yang buruk biasanya tidak memiliki keberanian dalam merencanakan, menilai, dan mengevaluasi kemampuan belajar mereka.

4) Kagan menyatakan, pendekatan metakognitif tidak dapat digunakan pada siswa yang tidak memiliki kemampuan membaca dan pemahaman yang baik (Alshammari, 2015).

\section{KESIMPULAN}

Kemampuan metakognisi merupakan kemampuan penting yang perlu dimiliki seorang siswa yang belajar. Melalui kemampuan ini, siswa dapat mengenal diri dan meningkatkan potensi/kemampuan yang dimilikinya. Pembelajaran matematika dengan menggunakan pendekatan keterampilan metakognitif membantu siswa untuk dapat terus mengembangkan kemampuan ini. Ketika kemampuan metakognisi siswa terus bertumbuh maka kualitas belajar siswa juga akan semakin baik dan hasil belajar yang maksimal bukanlah hal yang mustahil untuk dapat dicapai.

\section{DAFTAR PUSTAKA}

Alshammari, M. K. (2015). The Effect of Using Metacognitive Strategies for Achievement and the Trend Toward Social Studies for Intermediate Schools Students in Saudi Arabia. European Centre for Research Training and Development UK, 3(7), 47-54.

Blakey, E \& Spence, S. (1990). Developing Metacognitive. Dalam Eric Degests on Information Resources. Tersedia: http://files.eric.ed.gov/fulltext/ED327218.pdf (15 Januari 2018).

Bruce, M. \& Robinson, G. (2002). The Effectiveness of a Metacognitive Approach to Teaching Word Indentification Skills to Upper Primary Poor Readers. Special Education Perpectives, 11(1), 3-30.

Du Toit, S \& Kotze, G. (2009). Metacognitive Strategies in the Teaching and Learning of Mathematics. Pythagoras, 70, 57-67.

Flavell, J. H. (1976). Metacognitive Aspects of Problem Solving. In L. B. Resnick (Ed.), The Nature of Intelligence. Hillsdale, NJ: Elbaum. Tersedia: http://tip.psychology.org/meta.html (9 Mei 2009).

Huitt, W. (1997). Metacognition. Educational Psychology Interactive. Valdosta, GA: Valdosta

State University. Tersedia: http://www.edpsycinteractive.org/topics/cognition/metacogn.html (9 Mei 2009).

Kemendikbud. (2014). Konsep dan Implementasi Kurikulum 2013. Tersedia: https://kemdikbud.go.id/kemdikbud/dokumen/Paparan/Paparan\%20Wamendik.pdf (5 Januari 2018). 
Kramarski, B. \& Mevarech, Z. (2003). Metacognitive Discourse in Mathematics Classrooms. Proceedings of the Third Conference of the European Society for Research in Mathematics Education 28 February - 3 March 2003 Bellaria, Italia, pp. $1-9$.

Livingston, J. A. (2003). Metacognition: An Overview. Tersedia: https://files.eric.ed.gov/fulltext/ED474273.pdf (15 Januari 2018).

Lovett, M. C. (2008). Teaching Metacognition. Presentation to the Educause Learning Initiative Annual Meeting, 29 January 2008. Tersedia: https://serc.carleton.edu/NAGTWorkshops/metacognition/teaching_metacognition.ht $\mathrm{ml}$ (5 Januari 2018).

Mahdavi, M. (2014). An Overview: Metacognition in Education. International Journal of Multidisciplinary and Current Research, Vol.2, 529-535.

Ristekdikti. (2013). Peraturan Pemerintah Republik Indonesia Nomor 32 Tahun 2013. Tersedia: http://kelembagaan.ristekdikti.go.id/wpcontent/uploads/2016/08/PP0322013.pdf (12 Januari 2018).

Schoenfeld, A. H. (1992). Learning to Think Mathematically: Problem Solving, Matacognition, and Sense Making in Mathematics (Handbook for Research on Mathematics Teaching and Learning). New York: Macmillan. Tersedia: http://howtosolveit.pbworks.com/f/Schoenfeld_1992\%20Learning\%20to\%20Think\%2 0Mathematically.pdf (9 Mei 2009).

Sengul, S. \& Katranci, Y. (2012). Metacognitive Aspects of Solving Function Problems. Elseiver Ltd: Procedia - Social and Behavioral Sciences.

Sugiyono. (2013). Metode Penelitian Kuantitatif Kualitatif dan R\&D. Bandung: Alfabeta.

Suzana, Y. (2003). Meningkatkan Kemampuan Pemahaman dan Penalaran Matematik Siswa Sekolah Mengengah Umum (SMU) melalui Pembelajaran dengan Pendekatan Metakognitif. Tesis. PPS IKIP Bandung.

---------. (2004). Pembelajaran dengan Pendekatan Metakognitif untuk Meningkatkan Kemampuan Pemahaman Matematik Siswa SMU. Disajikan pada Seminar Nasional Matematika: Matematika dan Kontribusinya terhadap Peningkatan Kualitas SDM dalam Menyongsong Era Industri dan Informasi, Bandung, 15 Mei 2004.

Taccasu Project. (2008). Metacognition. Tersedia pada: http://www.hku.hk/cepc /taccasu/ref/metacognition.html (9 Mei 2009).

Tim Dosen. (2005). Pengelolaan Pendidikan. Bandung: Jurusan Administrasi Pendidikan UPI.

Tomo. (2003). Mengintegrasikan Teknik Membaca SQ4R dan Membuat Catatan Berbentuk Graphic Postorganiser dalam Pembelajaran Fisika. Disertasi. UPI.

Wilen, W. W \& Philips, J. A. (1995). Teaching Critical Thinking: A Metacognitive Approach. Social Education, 59 (3), 135-138.

Wall, K. \& Hall, E. (2016). Teachers as Metacognitive Role Model. European Journal of Teacher Education, Vol.36, 35-62. 